\title{
Biogas-fuelled Stirling engine for electric power generation
}

\author{
Ardiyansyah Yatim $^{1, *}$, Ade Luthfi ${ }^{1}$, and Raden Chemilo ${ }^{1}$ \\ ${ }^{1}$ Mechanical Engineering Department, Faculty of Engineering, Universitas Indonesia, Kampus UI Depok 16424, Indonesia
}

\begin{abstract}
The Stirling engine is an external combustion where the fuel combustion process takes place outside the cylinder. It offers flexibility of fuel used for the power generation, hence is a potential substitute to fossil fuelled internal combustion engine and contribute toward more sustainable power generation. In this study a Gamma V2-6 Stirling engine is used in a biogasfuelled power generation system. The engine has maximum capacity of $10 \mathrm{~kW}$. The required fuel input is $60,000 \mathrm{BTU} / \mathrm{hr}$ or equivalent to $17 \mathrm{~kW}$. The fuel is a biogas which comes from a biodigester. The system requires constant heat from the combustion chamber, hence a novel fuel distribution control is introduced. A specific burner is also designed to fulfil the purpose. In this study, a biogasfueled Stirling engine for electric power generation is designed and developed. The system has 5 $\mathrm{kW}$ capacity fuelled by $165 \mathrm{~kg} /$ day solid waste (biowaste) from local farm. The biodigester needed is $20 \mathrm{~m} 3$. Based on empirical model, the estimated energy efficiency of the system is $36 \%$. In addition, the system offers potential utilization of hot water as by side product.
\end{abstract}

\section{Introduction}

The growth of society requires continuous and sustainable energy in form of electricity from large scales industries to the communities of residential houses. That means more demands of the electricity generation system. Generally, energy sources that have been used mostly come from fossil fuels, such as coal, petroleum, natural gas and others. Fossil fuels are an energy resource whose formation takes millions of years and can be said to be non-renewable energy or known as conventional energy sources. Fossil energy use has caused an increase in greenhouse gases. Increased concentration of greenhouse gases is one of the causes of global warming. Therefore, alternative energy sources are needed to reduced greenhouse gases with renewable heat sources. In developing an eco-friendly electricity generation system, particular attention must be considered to increase the efficiency of the system and reducing the greenhouse gas emissions.

Gas and steam turbine usually installed in large scale electricity generation. While at small scales industries and communities, smaller capacity of electricity generations is needed.

Currently there are a lot of increased uses of biogas as a renewable fuel especially for small scales industries or communities. One of the reason is the availability of the biogas because it can be easily taken from livestock manure owned by small communities.

The composition of the gas generally consists of methane $\left(\mathrm{CH}_{4}\right)$ with a composition of $55 \%$ and carbon dioxide $\left(\mathrm{CO}_{2}\right)$ with a composition of $45 \%$. Methane gas as the main constituent of biogas is the second largest contributor to the greenhouse effect after $\mathrm{CO}_{2}$ [1]. The way to reduce the greenhouse effect from biogas is to burn the biogas for heating or as a generator fuel so that the compound becomes $\mathrm{CO}_{2}$ or $\mathrm{CO}$.

Biogas is taken from animal waste, especially cattle. The availability of cattle ranching is not a problem for the small community, which is common for generally has farms. Processing livestock manure such as cattle into biogas by using a tool called biodigester. In biodigester, animal waste is fermented to produce biogas in the reaction tank. In this study a biodigester which has been used in Kemakmuran area, Depok, Indonesia is used as the source of fuel for the power generation.

The produced biogas can then be used for heating for gas stoves as has been done by the people in the area or it can be used as fuel for electricity generation. The Stirling engine is one of the electricity generation engines which are using the external combustion process and compatible with biogas as a fuel.

The Stirling engine is a machine that uses the Stirling principle in the energy generation process. This machine is an external combustion engine because the fuel combustion process takes place outside the engine. The Stirling engine is used because the technology is environmentally friendly [2-7].

The Stirling engine used in this study is a Gamma Stirling V2-6 engine with $446 \mathrm{~cm}^{3}$ displacement volume and peak power generation of up to $10 \mathrm{~kW}$. The required fuel input is $60,000 \mathrm{BTU} / \mathrm{hr}$ or equivalent to $17 \mathrm{~kW}$. It is required to provide a stable fuel combustion heat and according to Stirling engine's specifications so that good electrification occurs.

The combustion chambers can be divided into two types according to the mixing way of air and natural gas: one type is the diffusion combustion chamber and the

\footnotetext{
Corresponding author: ardiyansyah@eng.ui.ac.id
} 
other type is the pre-mixing combustion chamber. Even though the diffusion combustion chamber incorporates a relatively simple structure and low cost, the flame is so long that it might eventually overheating the heater tubes of Stirling engine. Additionally, the second wind is required to make sure the combustion process is often nearly completed. Thus it is difficult to manage the temperature around the wall of heater tubes. If the combustion chamber is fully premixing structure, the combustion potency is higher and therefore the flame can be shorter, however, the manufacturing price should be higher because of the complex design of the premixing structure, and the temperature around the wall of heater tubes is not easy to be controlled. The study strives to design a burner and a combustion chamber for Stirling engine which uses biogas as a fuel source.

\section{Biogas-fuelled Stirling engine}

\subsection{Biogas fuel}

Biogas consists of various kinds of compounds. The main content of biogas is methane $\left(\mathrm{CH}_{4}\right)$ and carbon dioxide $\left(\mathrm{CO}_{2}\right)$. In addition, there are other compounds in biogas such as carbon monoxide (CO) and hydrogen sulphide $\left(\mathrm{H}_{2} \mathrm{~S}\right)$. Table 1 describes the percentage of volume-based biogas composition with various raw materials based on experiments from Ukpai and Nnabuchi in 2012 [8].

Table 1. Biogas composition by \% volume.

\begin{tabular}{|c|c|c|c|c|}
\hline $\begin{array}{c}\text { Raw } \\
\text { Material }\end{array}$ & $\mathrm{CO}_{2}$ & $\mathrm{H}_{2} \mathrm{~S}$ & $\mathrm{CO}$ & $\mathrm{CH}_{4}$ \\
\hline Cow dung & 27.2 & 0.1 & 4.7 & 67.9 \\
\hline Cowpea & 33.2 & 0.5 & 10.1 & 56.2 \\
\hline $\begin{array}{c}\text { Cassava } \\
\text { peeling }\end{array}$ & 32.2 & 3.1 & 13.3 & 51.4 \\
\hline
\end{tabular}

The biogas composition is influenced by biogas raw materials, a mixture of biogas raw materials with water, mixed temperature, and acidity. For example in the above experiment, the ratio of the mass of a mixture of cow dung and water is $1: 2$ with a mixture temperature of $36^{\circ} \mathrm{C}$.

The nature of biogas which is important in its function as fuel is the value of the heating value or calorific value. In biogas, this value is entirely determined by the percentage of methane gas content. The heating value of methane gas at $68^{\circ} \mathrm{F}$ and 14.7 psia are obtained as follows [8], the Higher Heating Value $(\mathrm{HHV})=23.890 \mathrm{BTU} / \mathrm{lb}$ or $994.7 \mathrm{BTU} / \mathrm{ft}^{3}$ and the Lower Heating Value $(\mathrm{LHV})=21,518 \mathrm{BTU} / \mathrm{lb}$ or 896.0 BTU $/ \mathrm{ft}^{3}$ in under standard conditions, namely temperature $32^{\circ} \mathrm{F}$ and pressure of 1 atm, the LHV value of dry biogas is determined below in table 2. The utilization of biogas varies from direct burning for cooking, heating and lighting to power generation through various combustion engine types.

Table 2. Biogas composition by \% volume [8]

\begin{tabular}{|c|c|c|c|c|c|}
\hline \multirow{2}{*}{$\begin{array}{l}\% \mathrm{CH}_{4} \\
\text { by volume }\end{array}$} & \multirow{2}{*}{$\mathrm{g} \mathrm{mol} \mathrm{wt}$} & \multirow{2}{*}{$\begin{array}{l}\mathrm{CH}_{4} \text { Percent } \\
\text { by weight }\end{array}$} & \multicolumn{2}{|c|}{ Density } & \multirow{2}{*}{$\begin{array}{c}\text { LHV } \\
\text { Btu/ft' } \\
\end{array}$} \\
\hline & & & Ibs d.g. $.^{*} / \mathrm{ft}^{2}$ & ft $/ / \mathrm{lb} \mathrm{d.g.}$ & \\
\hline $40 \%$ & 32.8 & $19.6 \%$ & 0.0916 & 10.92 & 385 \\
\hline $42 \%$ & 32.3 & $20.9 \%$ & 0.0900 & 11.11 & 405 \\
\hline $44 \%$ & 31.7 & $22.3 \%$ & 0.0885 & 11.30 & 424 \\
\hline $46 \%$ & 31.1 & $23.7 \%$ & 0.0869 & 11.50 & 443 \\
\hline $48 \%$ & 30.6 & $25.2 \%$ & 0.0854 & 11.71 & 463 \\
\hline $50 \%$ & 30.0 & $26.7 \%$ & 0.0838 & 11.93 & 482 \\
\hline $52 \%$ & 29.5 & $28.3 \%$ & 0.0822 & 12.16 & 501 \\
\hline $54 \%$ & 28.9 & $30.0 \%$ & 0.0807 & 12.39 & 520 \\
\hline $56 \%$ & 28.4 & $31.7 \%$ & 0.0791 & 12.64 & 540 \\
\hline $58 \%$ & 27.8 & $33.5 \%$ & 0.0776 & 12.89 & 559 \\
\hline $60 \%$ & 27.2 & $35.4 \%$ & 0.0760 & 13.16 & 578 \\
\hline $62 \%$ & 26.7 & $37.3 \%$ & 0.0744 & 13.43 & 598 \\
\hline $64 \%$ & 26.1 & $39.3 \%$ & 0.0729 & 13.72 & 617 \\
\hline $66 \%$ & 25.6 & $41.4 \%$ & 0.0713 & 14.02 & 636 \\
\hline $68 \%$ & 25.0 & $43.7 \%$ & 0.0698 & 14.34 & 655 \\
\hline $70 \%$ & 24.4 & $46.0 \%$ & 0.0682 & 14.66 & 675 \\
\hline * dry gas & & & & & \\
\hline
\end{tabular}

\subsection{Stirling engine}

Stirling engine offers several advantages compared to diesel and petroleum engines, e.g.: it is an external combustion engine, thermally regenerative, simple in construction, virtually quiet, safe in operation and flexible to adopt any heat sources such as solar, biomass, geothermal energy, or even an industrial waste. Stirling engine had wide applications, working conditions and performance of earlier stages [9].

The Stirling engine can be classified based on the configuration of the hot and cold space into three types i.e. alpha, beta and gamma. A comprehensive review of the three types of the Stirling engine is presented by Cheng and Yang [9].

An alpha Stirling contains two separate power pistons in separate cylinders, one "hot" piston and one "cold" piston. The hot piston cylinder is situated inside the higher temperature heat exchanger and the cold piston cylinder is situated inside the low-temperature heat exchanger. This type of engine has a very high power-to-volume ratio but has technical problems due to the usually high temperature of the "hot" piston and the durability of its seals.

A beta Stirling has a single power piston arranged within the same cylinder on the same shaft as a displacer piston. The displacer piston is a loose fit and does not extract any power from the expanding gas but only serves to shuttle the working gas from the hot heat exchanger to the cold heat exchanger. When the working gas is pushed to the hot end of the cylinder it expands and pushes the power piston. When it is pushed to the cold end of the cylinder it contracts and the momentum of the machine, usually enhanced by a flywheel, pushes the power piston the other way to compress the gas. Unlike the alpha type, the beta type avoids the technical problems of hot moving seals.

A gamma Stirling is simply a beta Stirling in which the power piston is mounted in a separate cylinder alongside the displacer piston cylinder, but is still 
connected to the same flywheel. The gas in the two cylinders can flow freely between them and remains a single body. This configuration produces a lower compression ratio but is mechanically simpler and often used in multi-cylinder Stirling engines.

Components of the Stirling engine are based on the Stirling brothers' design in 1840 [10] as shown in Figure 1. In this design, the regenerator and cooler are still separated from the Stirling engine. The main components are:

- Power Piston

The piston power serves to transmit the power created by the pressure to the engine crankshaft. The piston is made quite tight with a cylinder so that it can maintain the pressure difference for the Stirling engine.

\section{- Displacer}

Displacer moves the working fluid inside the cylinder. The displacer function traps the working fluid so that it is between hot space and cold space. The displacer is made loose against the cylinder so that it allows gas flow between the displacers. Displacer must be light and have low thermal conductivity to avoid heat flow from the working fluid to the displacer.

\section{- Heat Exchanger}

Heat Exchanger functions to transfer heat from and into the Stirling engine. In Figure 1, there are two heat exchangers which are to heat the gas and to cool it.

\section{- Regenerator}

Regenerator functions a temporary heat storage element so that the difference in temperature between hot space and cold space is maintained. Regenerators require low flow friction properties, high thermal capacity, but low thermal conductivity. Usually used metal wire mesh.

\section{- Working Fluid}

Working fluid as a substance that meets the Stirling engine and moves in a closed cycle. Working fluids which have low type density, high heat capacity, and high constant gas values.

Many technical challenges are encountered when manufacturing Stirling machines [6, 9-12], which include the following: the various configurations of Stirling engines represents a barrier against technology spread, regenerator characteristics have the greatest impact on engine performances, working gas leakage is a major difficulty when engine operates under high pressure, optimum rotation speed must be respected to ensure the machine proper functioning.

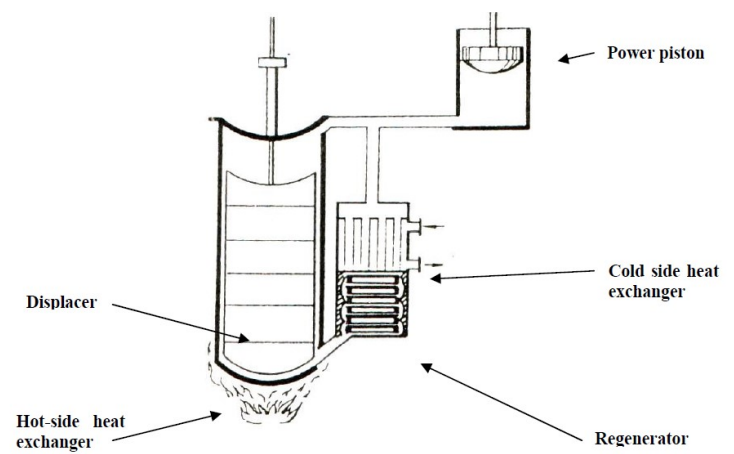

Fig. 1. Stirling engine original design [4]

\section{Experimental Setup}

The power generation system is built nearby the buried biodigester at the local farm. Biogas is generated from the biowaste of around 50 cows. For every 30 cows, the produced biowaste is about $10 \mathrm{~kg}$ per cow per day with estimated electric power equivalent of $33 \mathrm{kWh}$.

The biodigester is of a fixed-dome type. The accumulated biogas is continuously directed to outside of the biodigester. The biodigester is shown in Figure 2 . At peak session, the capacity of the biogas resulted up to $1,000 \mathrm{l} /$ day. The biogas is then directed and burned at the combustion chamber of the Stirling engine. In the Stirling engine, the combustion chamber is the most important component, because the performance of the Stirling engine is depends on the performance of the combustion inside the combustion chamber.
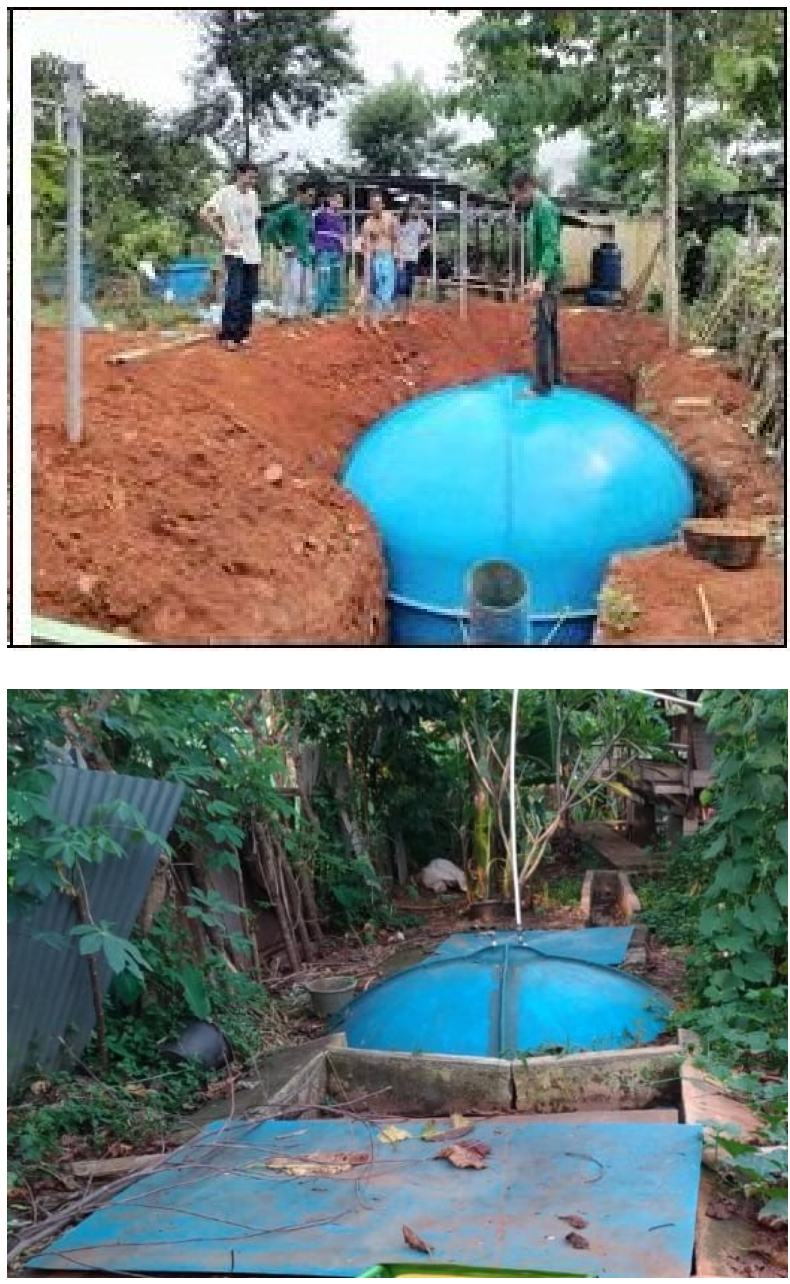

Fig. 2. Biodigester used in the present experiment at local farm in Depok, Indonesia

The combustion chamber that is designed for Stirling engine consists of three main parts; burner, heat exchanger cavity, and heater tube of Stirling engine. The combustion process only happens in burner. The fuel and fresh air are mixed prior to being ignited inside the burner. The design the structure of combustion chamber for Stirling engine is shown in Figure 3. The burner assembled on the top of heat exchange cavity, and heater 
tubes of Stirling engine are installed at the bottom of heat exchanger cavity. There is also air preheating layer in heat exchange cavity. The burner includes a fuel connection tube and igniter which is used to ignite biogas mixed with fresh air.

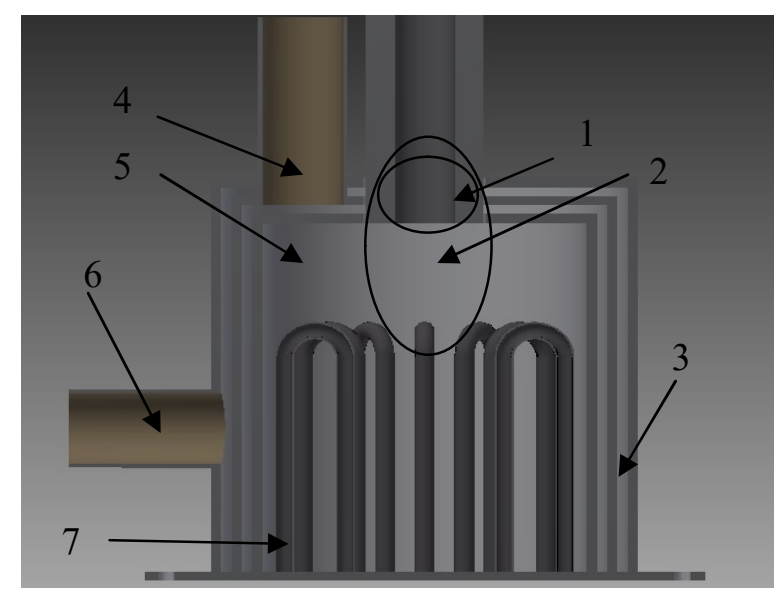

Fig. 3. The structure of designed combustion chamber for Stirling engine. 1. Ignition location; 2.Burner location; 3 . Air preheating layer; 4 . Emission exhaust; 5 . Heat exchanger cavity; 6 . Fresh air inlet; 7 . Heat tubes.

The power generation system is designed to utilized biogas and other biomass which then gasifier through fermentation process. The overall system is shown in Figure 4 where it is coupled with electric power generation either on or off grid. An inverter is used to control and synchronize the electric power output.

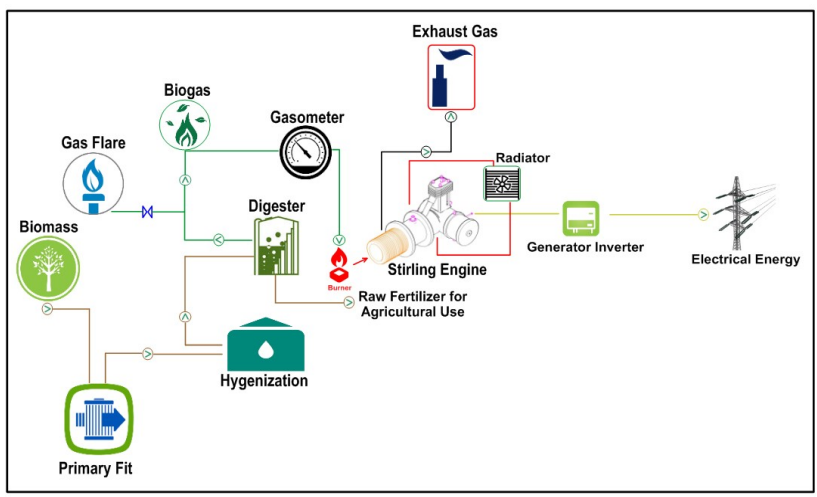

Fig. 4. Stirling engine power generation system

\section{Results and discussion}

The complete power generation system with Stirling engine is shown in Figure 5. The components include the biodigester, Stirling engine, a blower, a burner, the combustion chamber, control system, AC power inverter, and a fuel pump. Included within the Stirling engine are the alternator, heater, cooler, nitrogen, and water-to-air radiator (heat exchanger). The blower supplies the mass flow rate of atmospheric air to the system with a minimal pressure increase. The air is then heated in the preheater using the hot exhaust gases coming from the engine. The combustor burns the fuel increasing the air and gas mixture temperature to its operating point.

Figure 6 shows the construction plan of the power generation system with Stirling engine. It is located nearby the buried biodigester tank and connected by pipe system to direct the biogas. In addition the system also produce a by-product of hot water resulted from heat rejection at the heat exchanger of the Stirling engine.

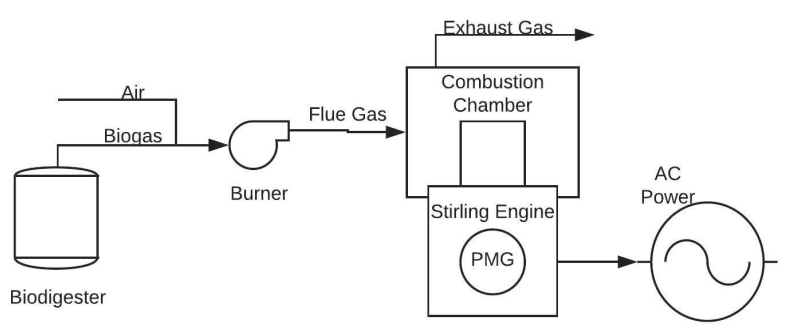

Fig. 5. Stirling engine system schematic diagram
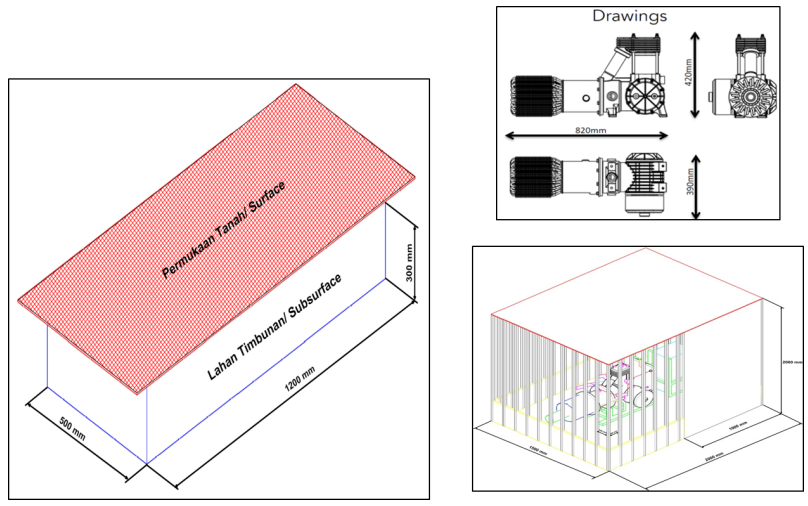

Fig. 6. Stirling engine power generation construction plan

The power capacity for the system is calculated and presented in Table 3. For a $5 \mathrm{~kW}$ electrical power generation with 8 hours of operation daily, the required biogas to fuel the system is about $20 \mathrm{~m}^{3}$.

Table 3. Calculation of power generation system capacity

\begin{tabular}{|c|c|c|c|}
\hline $\begin{array}{l}\text { Produced } \\
\text { Electricity }\end{array}$ & : & 5 & kW \\
\hline Operating Hours & : & 8 & Hours/Day \\
\hline Conversion & : & 243 & $\begin{array}{l}\text { kWh/tonnes biomass } \\
\text { (100\% organic) }\end{array}$ \\
\hline Feedstock & : & 0.165 & $\begin{array}{l}\text { tonnes/Day (if } 100 \% \\
\text { organic as the feedstock) }\end{array}$ \\
\hline $\begin{array}{l}\text { Volume Biogas } \\
\text { Reactor }\end{array}$ & . & $\begin{array}{l}165 \\
120 \\
1975\end{array}$ & $\begin{array}{l}\mathrm{kg} / \text { Day (if } 100 \% \text { organic } \\
\text { as the feedstock) } \\
\mathrm{m}^{3} / \text { tonnes biomass } \\
\text { (100\% organic) } \\
\mathrm{m}^{3} \text { biogas }\end{array}$ \\
\hline
\end{tabular}

Based on the model proposed in [2] the calculation of the capacity and system efficiency are obtained from the total solid work required and methane gas produced as shown below: 


$$
\begin{aligned}
T S & =27,7 \% \times Q \\
V S & =74,1 \% \times T S \\
V B S & =0,676 \times V S \\
V G M & =60 \% \times V B S
\end{aligned}
$$

where :

Q : solid waste (kg/Day)

TS : total solid (kg/Day)

VS : volatile solid ( $\mathrm{kg} /$ Day)

VBS : volume biogas production $\left(\mathrm{m}^{3} /\right.$ Day)

VGM: methane production $\left(\mathrm{m}^{3} /\right.$ Day)

The capacity and efficiency of the power generation system is presented in Table 4 . The power generation efficiency of $36 \%$ is obtained with $3.86 \mathrm{~kW}$ power capacities along 12 hours of operation per day or equivalent to $128 \mathrm{kWh}$ per day.

Table 4. Calculation of power generation system efficiency

\begin{tabular}{|llrl|}
\hline Q & $:$ & 165 & $\mathrm{~kg} /$ Day \\
TS & $:$ & 45.60 & $\mathrm{~kg} /$ Day \\
VS & $:$ & 33.79 & $\begin{array}{l}\mathrm{kg} / \text { Day } \\
\text { VBS }\end{array}$ \\
VGM & $:$ & 22.84 & $\begin{array}{l}\mathrm{m}^{3} \\
\mathrm{biogas}^{3}\end{array}$ \\
& $:$ & 13.70 & $\begin{array}{l}\text { methane/Day } \\
\text { Produced Electricity }\end{array}$ \\
Installed Capacity & $:$ & 128.68 & $\mathrm{kWh} /$ Day \\
Running Capacity & $:$ & 10.72 & $\mathrm{~kW}$ \\
\hline
\end{tabular}

\section{Conclusion}

In this study a a biogas-fuelled Stirling engine for electric power generation is designed and developed. The system utilizes a Gamma V2-6 Stirling engine. The engine has maximum capacity of $10 \mathrm{~kW}$. The required fuel input is $60,000 \mathrm{BTU} / \mathrm{hr}$ or equivalent to $17 \mathrm{~kW}$. The fuel is a biogas which comes from a biodigester. The system requires constant heat from the combustion chamber, hence a novel fuel distribution control is introduced. A specific burner is also designed to fulfil the purpose. The system has $5 \mathrm{~kW}$ electric power capacity fuelled by $165 \mathrm{~kg} /$ day solid waste (biowaste) from local farm. The biodigester needed is $20 \mathrm{~m}^{3}$. Based on empirical model, the estimated energy efficiency of the system is $36 \%$. In addition, the system offers potential utilization of hot water as by side product.

We express our gratitude to the Universitas Indonesia which has funded this research through the scheme of Hibah Publikasi Internasional Terindeks untuk Tugas Akhir Mahasiswa (PITTA) No.2382/UN2.R3.1/HKP.05.00/2018

\section{References}

[1] Environmental Protection Agency (EPA). EPA 430P-17-001. Washington DC (2017)

[2] McDonald, Tanya; Achari, Gopal; Abiola, Abimbola. J. of environmental eng. and sci. 7, 4 (2008)

[3] Obernberger I, Carlsen H, Biedermann F. International nordic bioenergy conference (2003)

[4] Richard K. Shaltens. EASA. 22nd Intersociety Energy Conversion Engineering Conference, International Energy Conversion Engineering Conference (1987)

[5] I. Urieli, D.M. Berchowitz. Adam Hilger, Bristol (1984)

[6] Houda Hachem, Ramla Gheith, Fethi Aloui, Sassi Ben Nasrallah. Energy Conversion and Management. 171 (2018)

[7] Ukpai, P.A. and Nnabuchi, M.M. Advances in Applied Science Research, 3 (2012)

[8] Eugene A. Avallone, Theodore Baumeister III, Ali M. Sadegh. McGraw-Hill 11 (2006)

[9] C.H. Cheng, H.S. Yang. Appl Energy, 92 (2012)

[10] G. Walker, R. Fauvel, R. Gustafson, J. van Bentham. Refrigeration, 5 (2) (1982)

[11] S.C. Costa, H. Barrutia, J.A. Esnaola, M. Tutar. Energy Convers Manage, 67 (2013)

[12] C.-H. Cheng, Y.-J. Yu. Renew Energy, 36 (2011) 